\title{
Effects of Iron-Steel Factory and Dense Traffic on Leaf Chemical Compounds of Six Tree Species in Turkey
}

\author{
Nezahat TURFAN ${ }^{1}$, Gamze SAVACI $^{2 *}$, Temel SARIYILDIZ ${ }^{3}$
}

${ }^{1}$ Kastamonu University, Faculty of Science and Art, Department of Biology, Kastamonu, TURKEY

${ }^{2}$ Kastamonu University, Faculty of Forestry,Department of Forest Engineering, Kastamonu,TURKEY

${ }^{3}$ Bursa Technical University, Faculty of Forestry, Department of Forest Engineering, Bursa,TURKEY

*Corresponding author: gsavaci@,kastamonu.edu.tr

Received Date: 16.02 .2018

Accepted Date: 18.09.2018

\section{Abstract}

Aim of study: Tree planting can play an important role in improving the quality of the urban environment. On the other hand, air pollutants can affect growth and health of trees. We studied the impacts of air pollution caused by the iron- steel factory and dense traffic on leaf chemical composition and also tree tolerance to the air pollution using six tree species (Maple, Ash tree, Cypress, Black pine, Sycamore and Aspen).

Material and Methods: The fresh leaf and needle sampling was carried out in April and July, and analyzed for photosynthetic pigments, peroxidation level, hydrogen peroxide, enzymatic antioxidants and non-enzymatic antioxidants.

Main results: Although there were statistically significant variations in the studied chemical compositions of the fresh leaf and needle samples between the six tree species, the pollution types and time, each chemical factor acted different ways with the pollution types and time according to tree species. In general, the pigment values, MDA, $\mathrm{H}_{2} \mathrm{O}_{2}$ and APX, concentrations in July were lower than those in April, whereas CAT, SOD, proline and protein concentrations in July were higher than those in April. Maple tree was more resistant to the traffic pollution, while Ash tree was more tolerant to both the pollution types. Among all trees, Aspen was found more susceptible to the traffic pollution

Research highlights: The results could be used in the future research directions to improve our understanding of the role of individual tree species in air pollution reduction and also set up a healthy, well managed urban forest which can provide many ecological benefits to urban environment.

Keywords: Air pollution, Chemical composition, Dense traffic, Iron-steel factory, Forest tree.

\section{Türkiye'de Yayılış Gösteren Altı Ağaç Türünün Yapraklarındaki}

\section{Kimyasal Bileşenlere Demir-Çelik Fabrikası ve Yoğun Trafiğin}

\section{Etkileri}

$\ddot{\mathbf{O z}}$

Çalışmanın amacı: Ağaçlandırma, kentsel çevrenin kalitesinin artırılmasında önemli bir rol oynamaktadır. Ancak, hava kirliliği ağaçların gelişimini ve sağlığını etkilemektedir. Bu çalışmada; demir-çelik fabrikası ve trafik kirliliğinin olduğu yerde bulunan altı ağaç türünün (Akçaağaç, Dişbudak, Servi, Karaçam, Çınar ve Kavak) yapraklarında kimyasal bileşenleri üzerindeki etkileri ve ayrıca bu ağaçların hava kirliliğine toleransı ortaya konulmuştur.

Materyal ve Yöntem: Yaprak ve iğne yaprak örnekleri Nisan ve Temmuz aylarında toplanılmıştır ve örneklerde fotosentetik pigmentler, lipit peroksidasyon ve hidrojen peroksit seviyesi, enzimatik ve non-enzimatik antioksidant bileşikler ölçülmüştür.

Sonuçlar: Ağaçlara ait yaprak ve iğne yaprak örneklerinde kimyasal bileşenler miktarında istatistiksel olarak önemli değişimler olmakla birlikte, her bir kimyasal değer, kirletici tipi, zaman ve ağaç çeşidine göre farklı etkilenmiştir. Çalışmada, pigment, $\mathrm{MDA}, \mathrm{H}_{2} \mathrm{O}_{2}$ ve APX değerleri Temmuz ayında daha düşüktür ancak CAT, SOD, prolin ve protein miktarı ise daha yüksektir. Akçaağaç trafik kirliliğine yüksek dayanım gösterirken, dişbudak ağacı her iki kirliliğe yüksek tolerans göstermiştir. Ağaçlar içerisinde kavak ağacı ise trafik kirliliğine duyarlı bulunmuştur.

Araştırma vurguları: $\mathrm{Bu}$ sonuçlar gelecekte yapılacak olan çalışmalarda ağaç türlerinin hava kirliliğinin indirgenmesindeki rollerinin anlaşılması ve sağlıklı bir şekilde düzenlenmesinde kullanılabildiği gibi kentsel çevreye yararlı ormanların yönetiminde de kullanılabilinir.

Anahtar kelimeler: Hava kirliliği, Kimyasal bileşikler, Yoğun trafik, Demir-Çelik fabrikası, Orman Ağacı 


\section{Introduction}

Increase in industrialization and motor vehicle usage has caused air pollution in all around the world, especially in crowded cities. Both pollution types result in accumulation of pollutants such as oxidized and reduced forms of carbon, sulphur and nitrogen, ozone, lead, volatile phenols, suspended particulate matter and also radioactive elements in the atmosphere (Seinfeld, 1986; Tobiszewski et al., 2018). Also they react with each other and produce the new toxic compounds. All pollutants can directly or indirectly repress plant growth and development by changing soil $\mathrm{pH}$ followed by solubilization of toxic salts of metals and accumulation of heavy metal in soil (Miller and McBride, 1999). Sarıyıldız, Savac1, \& Aljazwei (2017) said that soils may become contaminated by the accumulation of heavy metals and metalloids through emissions from the rapidly expanding industrial areas, mine tailings, disposal of high metal wastes, leaded gasoline and paints, land application of fertilizers, animal manures, sewage sludge, pesticides, wastewater irrigation, coal combustion residues. Trees planted in parks, gardens, near factories and roadsides are very important in the improvement of air quality in a city (Yang, McBride, Zhou \& Sun, 2005). Absorbing of pollutants by foliage and accumulation of them inside their organs can help reducing the pollution level in the air. Therefore, the use of trees as bioindicators of air quality and to maintain and determine the ecological balances are becoming more and more widespread (Oleksyn, 1988; Tripathi and Gautam, 2007). However, tree leaves are highly susceptible to the pollutants. The pollutants can form dirt layer on leaf surface and as the pollutants reach to extreme levels on leaf surface, they can reduce light penetration, prevent stomatal regulation. They can enter inside of cellular structures, and change physiological reactions of them (Halbwacts, 1984; Keller and Lamprecht, 1995). Recently, Bayhan (2016) has shown that the cement dust emissions have a negative effect on photosynthesis by covering the leaves of trees and reducing the amount of chlorophyll, carbohydrates and dry matter of the leaves.
Çavuşoğlu, Kılıç, \& Kılıç (2009) found that lead pollution increased the cuticle thickness for cedar and pine while it reduced the leaf diameter, vascular bundle size, stomata number, width and index. Also they noted that the stomata length decreased in cedar leaves, while it had no effect on this parameter in pine needles. Inside of tree tissues, the pollutants stimulate oxidative stress, lipid peroxidation, pigment degradation, lacking of relative water content, changing $\mathrm{pH}$ and inhibition of enzymes activities (Pukacka and Pukacki, 2000; Michalak, 2006). A study by Deniz (2010) showed that the air pollution by thermal power plant caused an increase in proline, total chlorophyll content, carotenoids, lipid peroxidation, SH-compounds, ascorbate and superoxide dismutase (SOD) but it reduced stomatal density. Y1lmaz (2015) found that $\mathrm{Pb}$, heavy metal degraded chlorophyll-a content but the amount of chlorophyll-b, chlorophyll a/b, total chlorophyll and carotenoid were destructed by $\mathrm{Cu}$, heavy metal in Bryum schleicheri. Iqbal, Shafig, Zaidi \& Athar (2015) determined that the vehicular activities induced an air pollution problem and reduced the level of chlorophyll pigments in trees which were exposed to road side pollution.

It has been noted for the pollution tolerant species that amount of enzymatic and nonenzymatic compounds such as phenolic, flavonoids, proline, ascorbate peroxidase, catalase and superoxide dismutase are increased (Michalak, 2006; Mutlu, Atıc1 \& Kaya, 2009). It seems that those chemicals increase the trees resistance to the pollution damages. Patykowski and Kołodziejek (2016) investigated the seasonal pattern of activity of SOD, CAT, GuPX, POD and the total protein concentration in the European mistletoe (Viscum album L. subsp. album) which were exposed to pollution with nitrogen dioxide, and they noted that the greater variations of SOD activity and total protein concentration were in Autumn, but only CAT activity was higher in late Spring. Also they have stated that the activity of SOD can mainly be used in the future as markers of the environment purity.

On the other hand, many researchers have expressed that tree reactions to the 
pollution can vary with season (Pandey and Agrawal, 1994, Sharma and Tripathi, 2009). Tree species tolerance to the air pollutants can be chosen by determining biochemical compounds by considering the seasonal variations.

Turkey has an impressive richness in terms of flora, earning it a prestigious place among the three continents. Such that, with nearly $30 \%$ of its total land area covered with forests, Turkey has 11000 plant species, almost totaling the number of plant species the whole continent of Europe has. On the other hand, Turkey is a developing country. Like other developing countries, Turkey also has many environmental problems caused by rapid development. Air pollution is the most outstanding of these. Increase in industrialization and motor vehicle usage cause serious health problems and loss of life, especially in crowded cities. People have known that trees can help to reduce air pollutants for a long time. In more recent times scientific studies have quantified the amount of air pollutants removed by trees in cities. Trees planted in parks, gardens, near factories and alongside roads can be also seen in Turkey. However, the effects of air pollution on those trees or tree tolerance to the air pollution haven't studied in details in Turkey. Therefore, in this present study, we aimed at (1) studying the impacts of air pollution caused by the iron / steel factory and dense traffics on tree chemical composition with seasonal and (2) finding out the better tree species to tolerance to air pollution using six common forest tree species as Maple (Acer negundo), Ash tree (Fraxinus excelcior), Cypress (Cupressus arizonica), Black pine (Pinus nigra),
Sycamore (Platanus orientalis) and Aspen (Populus tremula). Fresh leaf and needle samples were collected around iron steel factories and roadside trees in April and in July, and analyzed for their photosynthetic pigments, non-enzymatic and enzymatic compounds and level of lipid peroxidation and hydrogen peroxide.

\section{Materials and Methods \\ Study area and tree leaf sampling}

This study was carried out in Karabük province, northwest of Turkey $\left(40^{\circ} 05^{\prime}-\right.$ $40^{0} 15^{\prime} \mathrm{N}, 32^{0} 15^{\prime}-32^{0} 20^{\prime} \mathrm{E}$ ) (Fig. 1). Turkey's first heavy industry factory Kardemir Karabük Iron Steel Industry and Trade Inc. is among the top 50 industrial organizations in Turkey. The Factory hours are standard, even on weekends. Surface area of Karabük province is about $4.145 \mathrm{~km}^{2}$ and mean altitude of the city center is $280 \mathrm{~m}$. Although this area generally lies within the Black Sea climate zone, but the distance from the coast prevents it from benefiting from the humid weather of the Black Sea region. Annual average temperature is $13.2{ }^{\circ} \mathrm{C}$. Average monthly temperatures range from $23.1^{\circ} \mathrm{C}$ in July to $2.6{ }^{\circ} \mathrm{C}$ in January and annual average temperature variation is $20.5{ }^{\circ} \mathrm{C}$. In the province, moist mild climate with mild winter is influential with an annual rainfall of $600 \mathrm{~mm}$ and annual mean moisture is measured as $76 \%$. In Karabük, 93.020 hectares of total area are used as agricultural land and 271.403 hectares are covered by forest lands, while the rest are pastures, settlements and others. However, plant vegetation is dense throughout the mountains but scarce in the residential areas and surroundings.

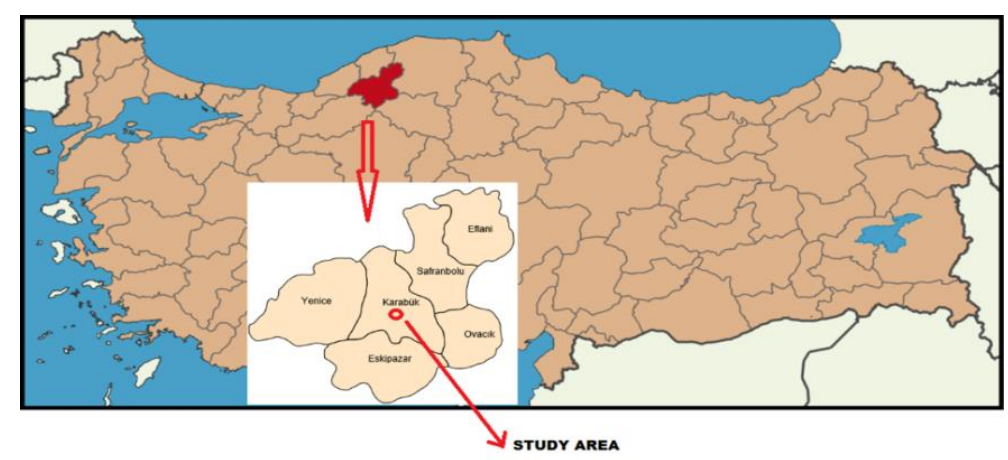

Figure 1. Location of the study area 
In order to study the effects of air pollution arise from the iron-steel factory and dense traffic in Karabük province, fully maturated fresh leaf and needle samples were collected from 6 different tree species (Acer negundo, Fraxinus excelsior, Cupressus arizonica, Pinus nigra, Platanus orientalis and Populus tremula) growing near the factory $(0-10 \mathrm{~m})$, and from the same tree species growing along the main roads, which were internationally used by all types of vehicles day and nights. Final fresh leaf and needle samples were taken from the same tree species as control samples growing further away (about 2000-3000 m away) from the polluted area (Figure 2 and Figure 3).
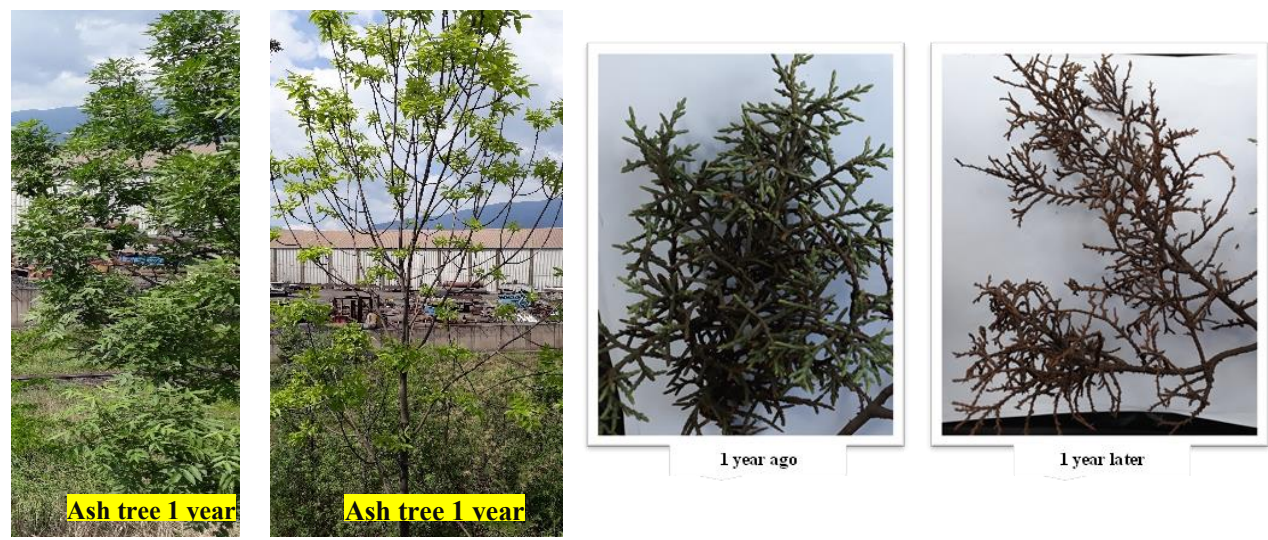

Figure 2. Visual differences between ash tree leaves and Arizona cypress needles after one year.

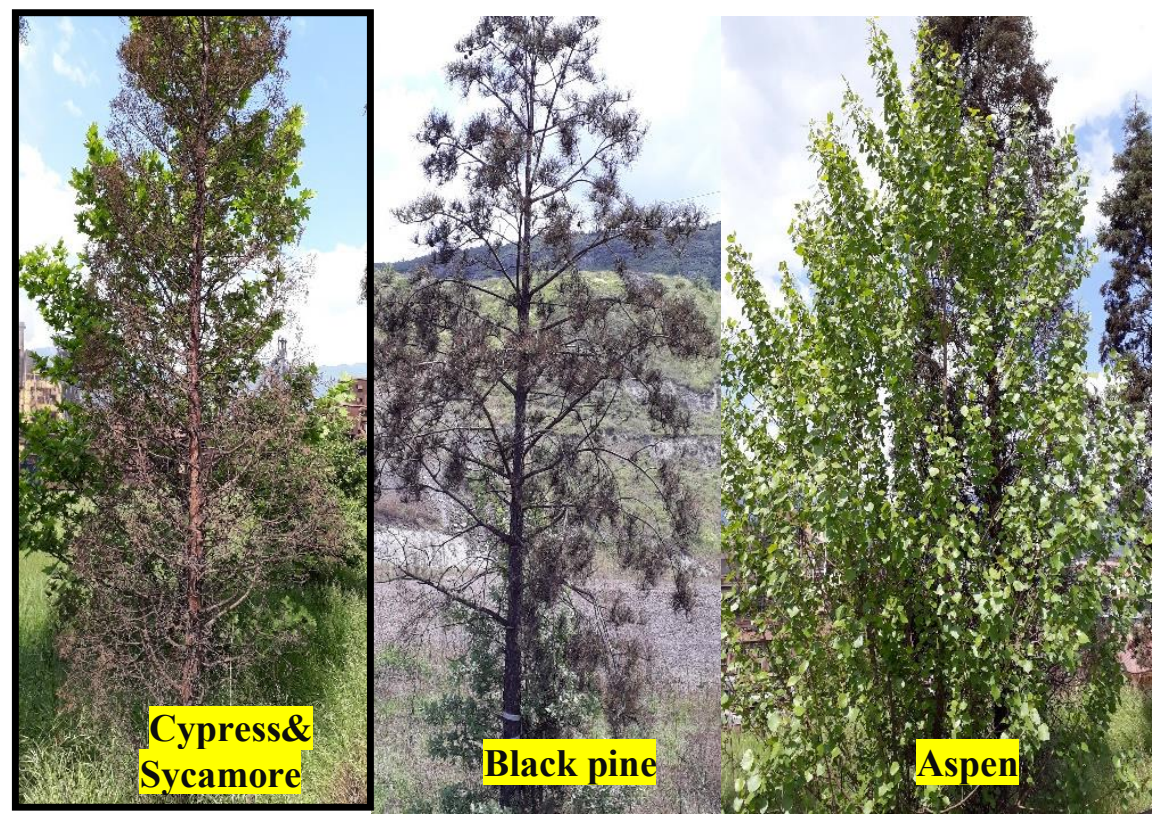

Figure 3. Some tree species (black pine, cypress and sycamore) are more heavily influenced by the air pollution than the other (aspen).

The age of the trees in the both study areas was determined by using an increment borer. Diameter measurements were made by calibrating the diameter of the standing at breast height $\left(\mathrm{d}_{1.30}\right)$. The height of the trees is measured by the The TruPulse 360 Rangefinder equipment in the areas (m). While the minimum and maximum average tree height measurements for maple samples varied between $6 \mathrm{~m}$ and $8 \mathrm{~m}$, mean tree diameters are between $10 \mathrm{~cm}$ and $12 \mathrm{~cm}$, and average tree ages are between 5 and 8 . While the minimum and maximum average tree height measurements for cypress samples varied between $8 \mathrm{~m}$ and $13 \mathrm{~m}$, mean tree diameters are between $12 \mathrm{~cm}$ and $18 \mathrm{~cm}$, and 
average tree ages are between 9 and 11 . While the minimum and maximum average tree height measurements for ash samples varied between $8 \mathrm{~m}$ and $11 \mathrm{~m}$, mean tree diameters are between $11 \mathrm{~cm}$ and $13 \mathrm{~cm}$, and average tree ages are between 5 and 7 . While the minimum and maximum average tree height measurements for black pine samples varied between $8 \mathrm{~m}$ and $10 \mathrm{~m}$, mean tree diameters are between $20 \mathrm{~cm}$ and $25 \mathrm{~cm}$, and average tree ages are between 16 and 17 .
While the minimum and maximum average tree height measurements for sycamore samples varied between $4 \mathrm{~m}$ and $5 \mathrm{~m}$, mean tree diameters are between $4 \mathrm{~cm}$ and $6 \mathrm{~cm}$, and average tree ages are between 6 and 8 . While the minimum and maximum average tree height measurements for aspen samples varied between $5 \mathrm{~m}$ and $8 \mathrm{~m}$, mean tree diameters are between $6 \mathrm{~cm}$ and $18 \mathrm{~cm}$, and average tree ages are between 5 and 8 (Table $1)$.

Table 1. Silvicultural characteristics of tree species affected by air pollution.

\begin{tabular}{cccc}
\hline Species & $\begin{array}{c}\text { Age } \\
\text { (year) }\end{array}$ & $\begin{array}{c}\text { Height } \\
(\mathbf{m})\end{array}$ & $\begin{array}{c}\text { Tree diameter } \\
\text { (cm) }\end{array}$ \\
\hline Maple & $5-6$ & 6 & $10-11$ \\
\hline & $7-8$ & 8 & $12-13$ \\
\hline Cypress & $6-7$ & 7 & $10-12$ \\
\hline & 10 & $12-13$ & $17-18$ \\
\hline Ash & 11 & 8 & 13 \\
\hline & $9-10$ & $8-9$ & $12-14$ \\
\hline & 6 & 8 & $12-13$ \\
\hline Black pine & $5-6$ & 12 & 13 \\
\hline & $6-7$ & 11 & $11-12$ \\
\hline Sycamore & 17 & $9-10$ & $22-25$ \\
\hline 2 & 16 & $9-10$ & $20-23$ \\
\hline 3 & 17 & $8-9$ & $22-24$ \\
\hline Aspen & $6-7$ & 4 & $4-5$ \\
\hline 2 & $7-8$ & 4.5 & $5-6$ \\
\hline 3 & $6-7$ & $4-5$ & $5-6$ \\
\hline & 8 & 5 & $17-18$ \\
\hline
\end{tabular}

For each tree species, the fully maturated fresh leaves and needles were collected from 3 trees and combined to form a mixed sample. The fresh leaf and needle samples were carried out in April and July, with the exception of Sycamore leaf in April was not sampled due to poor leaf development. The sample trees around the factory were chosen on the basis of the wind direction, where the effect of the pollution is thought to be the highest. Dust accumulation of capacity and pollutant damage to trees depends on leaf characteristics such as surface geometry, phyllotaxy, leaf external properties and seasonal leaf development status. And also it was not possible to take a sample from the same tree in the second year due to the death of leaf, branch and whole. Therefore, the leaf sample were sampled two times as spring and summer (Katiyar and Dubey, 2001; Sharma \& Tripathi, 2009). After the sampling, the dust particles on the leaves and needles were cleaned with tap water and then they were cleaned by deionized water three times. The samples were taken with the nematic dry paper and they were used for chemical analysis. All analysis was performed in triplicate. 
In addition, the amount of particulate matter arisen from the iron-steel factory, traffic pollution and retained on leaves was examined according to Prusty, Mishra \& Azeez, (2015). The particulate matters were collected from 15-20 pieces of leaves. Each leaf was held individually with tweezers and the particulate matter deposited on leaf surfaces was washed using a no hair-loss brush. And then, the leaves were washed using about $5 \mathrm{~mL}$ distilled water. The entire procedure typically took less than $10 \mathrm{~min}$, minimizing the water-soluble particles.

\section{Chemical Analyses of Leaf and Needle Samples}

Chlorophyll content of the leaves and needles was measured by the method of Arnon (1949). Carotenoid amount was estimated by Jaspars Formula according to the method by Witham, Blaydes \& Devli (1971). Proline content was determined according to the modified method of Bates, Waldern \& Teare (1973). Total soluble protein contents were determined according to the method of Bradford (1976) using the Bio-Rad assay kit with bovine serum albumin as a calibration standard. The level of lipid peroxidation products was determined and expressed as MDA content according to Lutts, Kinet \& Bouharmont (1996). Hydrogen peroxide in the plant samples was determined by the method of Velikova, Yordanov \& Edreva (2000). The total phenolic content of leaf samples was determined spectrophotometrically using the Folin-Ciocalteu method (Singleton, Orthofer \& Lamuela-Raventós, 1999). The total flavonoid content by spectrophotometrically according to Kumaran and Karunakaran (2006).

Antioxidant of the leaf and needle samples was determined by using dry leaf and needle samples $(500 \mathrm{mg})$. The dried leaf and needle samples were grinded in powder using nitrogen liquid. The powder was homogenized in $5 \mathrm{~mL}$ phosphate potassium $(\mathrm{pH} \quad 7.6$ with $0.1 \mathrm{mM}$ of EDTA-
Ethylenediaminetetraacetic acid). The homogenate was centrifuged to $15.000 \mathrm{x}$ g for $20 \mathrm{~min}$ at $4^{\circ} \mathrm{C}$. The supernatant was kept, and $0.8 \mathrm{ml}$ phosphate potassium $0.2 \mathrm{M}$ was added. The homogenate was centrifuged again to $15.000 \mathrm{x} \mathrm{g}$ during $15 \mathrm{~min}$. The combined supernatants were stored on ice and used in order to determine the activity of detoxifying enzymes. The activity of SOD was assayed by measuring its ability to inhibit the photochemical reduction of NBT (nitro blue tetrazolium), adopting the method of Cakmak (1994). The activity of CAT was determined by Bergmeyer (1970), APX was assayed following the procedure described by Nakano and Asada (1981). APX and CAT were expressed per $\mathrm{mg}$ protein, and one unit represented $1 \mu \mathrm{mol}$ of substrate undergoing reaction per $\mathrm{mg}$ protein per min. The particulate matter was also analyzed for element concentrations using SPECTRO brand XEPOS model XRF instrument at Central Research Laboratory at Kastamonu University.

\section{Statistical Analysis}

Analysis of variance (ANOVA) was applied for analyzing the differences in the chemical composition of the leaf and needle samples from six tree species collected in April and July and exposed to air and traffic pollutions using the SPSS program (Version 11 for Windows). Following the results of ANOVAs, Tukey's honestly significant difference (HSD) test ( $\alpha=0.05$ was used for significance.

\section{Results \\ Element concentrations in the particulate matter}

Mean element concentrations of the particulate matter on the leaf samples exposed to iron-steel factory pollution are shown in Table 2. As it was expected, the element concentrations in the particulate matter were found to be much higher. 
Table 2. Mean element concentrations of the particulate matter on the leaf samples exposed to iron-steel factory pollution (AP) and traffic pollution (TP).

\begin{tabular}{|c|c|c|c|c|c|c|c|}
\hline & \multicolumn{3}{|c|}{$\mathbf{A P}$} & \multicolumn{4}{|c|}{ TP } \\
\hline & ppm & & ppm & & ppm & & ppm \\
\hline $\mathrm{Na}$ & $55.9 \pm 10.070$ & Se & $48.3 \pm 0.004$ & $\mathbf{N a}$ & $1123 \pm 20$ & $\mathrm{Br}$ & $181.82 \pm 0.26$ \\
\hline Mg & $47.9 \pm 1.200$ & $\mathrm{Br}$ & $1548.8 \pm 0.122$ & Mg & $5260.5 \pm 40.60$ & $\mathbf{S r}$ & $1.23 \pm 0.08$ \\
\hline $\mathbf{A l}$ & $357.4 \pm 2.191$ & $\mathbf{R b}$ & $295.2 \pm 0.016$ & Al & $1203.85 \pm 8.02$ & $\mathbf{Y}$ & $0.17 \pm 0.06$ \\
\hline $\mathbf{S i}$ & $2033.2 \pm 5.225$ & $\mathrm{Sr}$ & $319.9 \pm 0.017$ & $\mathbf{S i}$ & $7532.5 \pm 13.2$ & $\mathrm{Zr}$ & $5.35 \pm 0.6$ \\
\hline $\mathbf{P}$ & $81.5 \pm 0.089$ & $\mathbf{Y}$ & $52.9 \pm 0.003$ & $\mathbf{P}$ & $2257.5 \pm 4.2$ & Mo & $2.48 \pm 0.32$ \\
\hline $\mathbf{S}$ & $3029.5 \pm 1.780$ & $\mathbf{Z r}$ & $16.6 \pm 0.015$ & $\mathbf{S}$ & $5670.5 \pm 5.60$ & $\mathbf{A g}$ & $5.82 \pm 0.42$ \\
\hline Cl & $35324 \pm 4.186$ & Mo & $0.39 \pm 0.001$ & Cl & $2539.33 \pm 2.2$ & Cd & $2.48 \pm 0.32$ \\
\hline $\mathbf{K}$ & $644.3 \pm 1.078$ & Cd & $22.1 \pm 0.03$ & $\mathbf{K}$ & $17943.33 \pm 22$ & Sn & $5.82 \pm 0.42$ \\
\hline $\mathbf{C a}$ & $4906.3 \pm 6.582$ & Sn & $49.9 \pm 0.035$ & $\mathbf{C a}$ & $30791.67 \pm 32$ & Te & $9.93 \pm 0.48$ \\
\hline $\mathbf{T i}$ & $279 \pm 0.215$ & Sb & $4.20 \pm 0.0005$ & Ti & $81.83 \pm 1.11$ & I & $5.73 \pm 0.72$ \\
\hline $\mathbf{V}$ & $71.2 \pm 0.038$ & Te & $23.1 \pm 0.013$ & $\mathbf{V}$ & $12.82 \pm 0.58$ & CS & $21.60 \pm 2.18$ \\
\hline $\mathrm{Cr}$ & $20.4 \pm 0.005$ & I & $60.5 \pm 0.029$ & $\mathbf{C r}$ & $7.9 \pm 0.20$ & $\mathbf{B a}$ & $36.10 \pm 3.36$ \\
\hline Mn & $2615.9 \pm 0.501$ & $\mathbf{B a}$ & $329.9 \pm 0.550$ & Mn & $246.48 \pm 0.98$ & La & $6.52 \pm 0.94$ \\
\hline $\mathbf{F e}$ & $73377.6 \pm 25.840$ & Pr & $8.41 \pm 0.002$ & $\mathrm{Fe}$ & $3601.43 \pm 6.20$ & Ta & $21.28 \pm 0.72$ \\
\hline Co & $3.27 \pm 0.002$ & Nd & $14.5 \pm 0.001$ & Co & $7.50 \pm 1.42$ & W & $0.67 \pm 0.08$ \\
\hline $\mathbf{N i}$ & $29.6 \pm 0.007$ & $\mathbf{Y b}$ & $16.3 \pm 0.003$ & Ni & $14.77 \pm 0.32$ & $\mathrm{Hg}$ & $0.53 \pm 0.04$ \\
\hline $\mathbf{C u}$ & $61.8 \pm 0.014$ & Ta & $29.9 \pm 0.013$ & $\mathbf{C u}$ & $12.87 \pm 0.32$ & $\mathbf{P b}$ & $12.15 \pm 0.26$ \\
\hline $\mathbf{Z n}$ & $85577.7 \pm 5.070$ & TI & $58.9 \pm 0.001$ & Zn & $126.52 \pm 0.56$ & & \\
\hline Ga & $95.9 \pm 0.011$ & $\mathbf{P b}$ & $10691.4 \pm 2.002$ & $\mathbf{G a}$ & $1.25 \pm 0.20$ & & \\
\hline $\mathbf{G e}$ & $13.2 \pm 0.002$ & $\mathbf{B i}$ & $2151.1 \pm 0.345$ & As & $1.82 \pm 0.14$ & & \\
\hline As & $319.4 \pm 0.039$ & & & Se & $9.63 \pm 0.12$ & & \\
\hline
\end{tabular}

\section{Variation in photosynthetic pigments} (chlorophyll-a, and -b, total chlorophyll)

Mean concentrations of photosynthetic pigments (chlorophyll-a, and -b, total chlorophyll) in the leaf and needle samples of six tree species collected in April and July and exposed to air and traffic pollutions are shown in Table 3. The single effects and interactions of tree species, pollution types and sample colleting time are listed in Table 4. The main effects of species, pollution type and time on the photosynthetic pigments were all significant $(\mathrm{P}<0.001)$. Tree species $\mathrm{x}$ pollution types $\mathrm{x}$ time interactions were also significant for the photosynthetic pigments indicating that the photosynthetic pigments behave in different ways with the different pollution type and time according to tree species. These variations in photosynthetic pigments are explained below using mean total chlorophyll concentrations.

Mean total chlorophyll concentration in the control samples in April was in order as Aspen $(0.277 \mathrm{mg} / \mathrm{g})>$ Cypress $(0.259 \mathrm{mg} / \mathrm{g})$ $>$ Black pine $(0.185 \mathrm{mg} / \mathrm{g})>$ Ash tree $(0.171$ $\mathrm{mg} / \mathrm{g})>$ Maple $(0.151 \mathrm{mg} / \mathrm{g})$. Compared to
April samples, in July samples, mean total chlorophyll concentrations showed a decrease for Maple, Ash tree and Cypress, whereas it showed an increase for Black pine and Aspen. However, it showed similar order among tree species as noted in April; Aspen $(0.387 \mathrm{mg} / \mathrm{g})>$ Cypress $(0.250 \mathrm{mg} / \mathrm{g})>$ Black pine $(0.248 \mathrm{mg} / \mathrm{g})>$ Ash tree $(0.105$ $\mathrm{mg} / \mathrm{g})>$ Maple $(0.101 \mathrm{mg} / \mathrm{g})$.

Under the air polluted sites, all three species, except Aspen which had similar values with the control samples, showed an increase in April samples; $0.242 \mathrm{mg} / \mathrm{g}$ for Acer, $0.279 \mathrm{mg} / \mathrm{g}$ for Ash tree, $0.302 \mathrm{mg} / \mathrm{g}$ for Cypress, $0.73 \mathrm{mg} / \mathrm{g}$ for Black pine and $0.265 \mathrm{mg} / \mathrm{g}$ for Aspen. However, in July samples, compared to the control samples, most tree species showed a decrease in mean total chlorophyll concentration; $0.100 \mathrm{mg} / \mathrm{g}$ for Maple, $0.154 \mathrm{mg} / \mathrm{g}$ for Ash tree, 0.185 $\mathrm{mg} / \mathrm{g}$ for Cypress, $0.216 \mathrm{mg} / \mathrm{g}$ for Black pine, 0.244 for Sycamore and $0.313 \mathrm{mg} / \mathrm{g}$ for Aspen.

Under the traffic polluted sites, in April samples, Maple, Black pine and Aspen tree species showed an increase in mean total chlorophyll concentration; $0.220 \mathrm{mg} / \mathrm{g}$ for 
Maple, $0.245 \mathrm{mg} / \mathrm{g}$ for Black pine and 0.284 $\mathrm{mg} / \mathrm{g}$ for Aspen, whereas Ash tree and Cypress showed a decrease; $0.156 \mathrm{mg} / \mathrm{g}$ for Ash tree and $0.246 \mathrm{mg} / \mathrm{g}$ for Cypress. In July samples; Maple, Ash tree and Cypress tree species showed an increase in mean total chlorophyll concentration; $0.112 \mathrm{mg} / \mathrm{g}$ for
Maple, $0.126 \mathrm{mg} / \mathrm{g}$ for Ash tree and 0.282 $\mathrm{mg} / \mathrm{g}$ for Cypress, whereas Aspen showed a decrease $(0.313 \mathrm{mg} / \mathrm{g})$. Black pine and Sycamore, however, showed similar mean total chlorophyll concentrations compared to the control sites; $0.246 \mathrm{mg} / \mathrm{g}$ for Black pine and $0.279 \mathrm{mg} / \mathrm{g}$ for Sycamore.

Table 3. Mean chlorophyll a, chlorophyll b, total chlorophyll concentrations, and chlorophyll $\mathrm{a} / \mathrm{b}$ ratios in fresh leaves of 6 different tree species collected from air (AP) and traffic polluted (TP) and control (C) sites at two different times (April and July).

\begin{tabular}{|c|c|c|c|c|c|c|c|c|c|}
\hline \multirow{2}{*}{$\begin{array}{c}\text { Tree } \\
\text { species }\end{array}$} & \multirow{2}{*}{$\begin{array}{c}\text { Pollution } \\
\text { Types }\end{array}$} & \multicolumn{2}{|c|}{$\begin{array}{c}\text { Chlorophyll a } \\
\text { (mg/g) }\end{array}$} & \multicolumn{2}{|c|}{$\begin{array}{c}\text { Chlorophyll b } \\
\text { (mg/g) }\end{array}$} & \multicolumn{2}{|c|}{$\begin{array}{c}\text { Total Chlorophyll } \\
\text { Ll (mg/g) }\end{array}$} & \multicolumn{2}{|c|}{$\begin{array}{c}\text { Chlorophyll } \\
\text { a/b }\end{array}$} \\
\hline & & April & July & April & July & April & July & April & July \\
\hline \multirow{3}{*}{ Maple } & $\mathrm{C}$ & 0.136 & 0.088 & 0.016 & 0.014 & 0.151 & 0.101 & $8.6: 1$ & $6.5: 1$ \\
\hline & AP & 0.172 & 0.073 & 0.070 & 0.027 & 0.242 & 0.100 & $2.5: 1$ & $2.7: 1$ \\
\hline & $\mathrm{TP}$ & 0.161 & 0.092 & 0.059 & 0.020 & 0.220 & 0.112 & 2.8:1 & 4.6:1 \\
\hline \multirow{3}{*}{ Ash tree } & $\mathrm{C}$ & 0.124 & 0.086 & 0.048 & 0.020 & 0.171 & 0.105 & $2.6: 1$ & $4.4: 1$ \\
\hline & AP & 0.165 & 0.113 & 0.115 & 0.042 & 0.279 & 0.154 & $1.4: 1$ & $2.7: 1$ \\
\hline & $\mathrm{TP}$ & 0.114 & 0.099 & 0.042 & 0.028 & 0.156 & 0.126 & $2.7: 1$ & $3.6: 1$ \\
\hline \multirow{3}{*}{ Cypress } & $\mathrm{C}$ & 0.157 & 0.163 & 0.103 & 0.088 & 0.259 & 0.250 & $1.5: 1$ & $1.9: 1$ \\
\hline & AP & 0.152 & 0.132 & 0.150 & 0.054 & 0.302 & 0.185 & 1.0:1 & $2.5: 1$ \\
\hline & $\mathrm{TP}$ & 0.158 & 0.160 & 0.089 & 0.122 & 0.246 & 0.282 & 1.8:1 & 1.3:1 \\
\hline \multirow{3}{*}{ Black pine } & $\mathrm{C}$ & 0.140 & 0.177 & 0.045 & 0.072 & 0.185 & 0.248 & $3.1: 1$ & $2.5: 1$ \\
\hline & AP & 0.170 & 0.148 & 0.105 & 0.068 & 0.273 & 0.216 & $1.6: 1$ & $2.2: 1$ \\
\hline & $\mathrm{TP}$ & 0.171 & 0.174 & 0.074 & 0.072 & 0.245 & 0.246 & 2.3:1 & 2.4:1 \\
\hline \multirow{3}{*}{ Sycamore } & $\mathrm{C}$ & n.a. & 0.184 & n.a. & 0.096 & n.a. & 0.280 & n.a. & $1.9: 1$ \\
\hline & $\mathrm{AP}$ & n.a. & 0.171 & n.a. & 0.073 & n.a. & 0.244 & n.a. & 2.4:1 \\
\hline & $\mathrm{TP}$ & n.a. & 0.184 & n.a. & 0.096 & n.a. & 0.279 & n.a. & $1.9: 1$ \\
\hline \multirow{3}{*}{ Aspen } & $\mathrm{C}$ & 0.168 & 0.193 & 0.109 & 0.195 & 0.277 & 0.387 & $1.6: 1$ & $1.0: 1$ \\
\hline & AP & 0.173 & 0.195 & 0.093 & 0.119 & 0.265 & 0.313 & 1.9:1 & $1.7: 1$ \\
\hline & $\mathrm{TP}$ & 0.157 & 0.199 & 0.127 & 0.157 & 0.284 & 0.355 & $1.2: 1$ & $1.3: 1$ \\
\hline
\end{tabular}

C: control, AP: Air polluted sites, TP: Traffic polluted sites, n.a.: not available

Table 4. ANOVA results for mean chlorophyll $\mathrm{a}$ and $\mathrm{b}$ data.

\begin{tabular}{ccccccc}
\hline & Source & $\begin{array}{c}\text { Type III } \\
\text { Sum of } \\
\text { Squares }\end{array}$ & df & $\begin{array}{c}\text { Mean } \\
\text { Square }\end{array}$ & F & $\begin{array}{c}\text { Partial Eta } \\
\text { Squared }\end{array}$ \\
\hline & Tree species (TS) &, 068 & 5 &, 014 & $4800,743 * * *$ &, 997 \\
& Pollution Type (PT) &, 001 & 2 &, 000 & $97,195 * * *$ &, 747 \\
Chlorophyll & Time (T) &, 005 & 1 &, 005 & $1786,964 * * *$ &, 964 \\
a & TS x PT &, 007 & 10 &, 001 & $234,379 * * *$ &, 973 \\
& TS x T &, 028 & 4 &, 007 & $2486,955^{* * *}$ &, 993 \\
& PT x T &, 004 & 2 &, 002 & $719,385^{* * *}$ &, 956 \\
& TS x PT x T &, 002 & 8 &, 000 & $107,664 * * *$ &, 929 \\
Chlorophyll & & & & &, 998 \\
b & Tree species (TS) &, 115 & 5 &, 023 & $5893,678^{* * *}$ &, 899 \\
& Pollution Type (PT) &, 002 & 2 &, 001 & $294,540^{* * *}$ &, 894 \\
& Time (T) &, 002 & 1 &, 002 & $556,984 * * *$ &, 986 \\
& TS x PT &, 018 & 10 &, 002 & $471,705 * * *$ &, 988 \\
& TS x T &, 021 & 4 &, 005 & $1336,445 * * *$ &, 982 \\
& PT x T &, 014 & 2 &, 007 & $1803,381 * * *$ &, 974 \\
\hline
\end{tabular}


Table 4 (continued)

\begin{tabular}{ccccccc}
\hline & Tree species (TS) &, 336 & 5 &, 067 & $6430,067 * * *$ &, 998 \\
Total & Pollution Type (PT) &, 005 & 2 &, 003 & $239,985 * * *$ &, 879 \\
Chlorophyll & Time (T) &, 014 & 1 &, 014 & $1326,403 * * *$ &, 953 \\
& TS x PT &, 036 & 10 &, 004 & $340,544 * * *$ &, 981 \\
& TS x T &, 086 & 4 &, 021 & $2053,278 * * *$ &, 992 \\
& PT x T &, 033 & 2 &, 017 & $1594,113 * * *$ &, 980 \\
& TS x PT x T &, 012 & 8 &, 002 & $148,339 * * *$ &, 947 \\
Crror &, 001 & 66 & $1,04 \mathrm{E}-005$ & &, 986 \\
Chlorophyll & Tree species (TS) & 120,237 & 5 & 24,047 & $925,743 * * *$ &, 935 \\
& Pollution Type (PT) & 24,491 & 2 & 12,245 & $471,404 * * *$ &, 554 \\
& Time (T) & 2,126 & 1 & 2,126 & $81,825 * * *$ &, 975 \\
& TS x PT & 66,578 & 10 & 6,658 & $256,301 * * *$ &, 799 \\
& TS x T & 6,835 & 4 & 1,709 & $65,780^{* * *}$ &, 656 \\
PT x T & 3,276 & 2 & 1,638 & $63,048 * * *$ &, 887
\end{tabular}

\section{Variation in MDA and $\mathrm{H}_{2} \mathrm{O}_{2}$}

Mean concentrations of MDA and $\mathrm{H}_{2} \mathrm{O}_{2}$ are shown in Table 5. The single effects and interactions of tree species, pollution types and sample colleting time are listed in Table 6. The main effects of species, pollution type and time on mean MDA and $\mathrm{H}_{2} \mathrm{O}_{2}$ were all significant $(\mathrm{P}<0.001)$. Tree species $\mathrm{x}$ pollution types $\mathrm{x}$ time interactions were also significant for mean MDA and $\mathrm{H}_{2} \mathrm{O}_{2}$ were indicating that mean MDA and $\mathrm{H}_{2} \mathrm{O}_{2}$ were behave in different ways with the different pollution type and time according to tree species.

Mean MDA concentration in April samples for all 6 tree species were also higher than in July samples, whereas mean $\mathrm{H}_{2} \mathrm{O}_{2}$ concentration showed different ways according to the tree species. For Maple, Cypress and Aspen, mean $\mathrm{H}_{2} \mathrm{O}_{2}$ concentration in April samples were lower than in July samples, while for Ash tree and Black pine, mean $\mathrm{H}_{2} \mathrm{O}_{2}$ concentration in April samples were higher than in July samples (Table 5). Variation in mean MDA concentration was depended on tree species and time, but mean $\mathrm{H}_{2} \mathrm{O}_{2}$ concentration in the air or traffic polluted samples were notably higher than the control samples (Table 5).

Table 5. Mean MDA and $\mathrm{H}_{2} \mathrm{O}_{2}$ concentrations in fresh leaves of 6 different tree species collected from air (AP) and traffic polluted (TP) and control (C) sites at two different times (April and July).

\begin{tabular}{|c|c|c|c|c|c|}
\hline \multirow{2}{*}{ Tree species } & \multirow{2}{*}{$\begin{array}{l}\text { Pollution } \\
\text { Type }\end{array}$} & \multicolumn{2}{|c|}{ MDA $\mu \mathrm{mol} / \mathrm{g}$} & \multicolumn{2}{|c|}{$\mathrm{H}_{2} \mathrm{O}_{2} \mu \mathrm{mol} / \mathrm{g}$} \\
\hline & & April & July & April & July \\
\hline \multirow{3}{*}{ Maple } & $\mathrm{C}$ & 67.6 & 13.6 & 64 & 78 \\
\hline & AP & 57.4 & 18.7 & 66 & 134 \\
\hline & $\mathrm{TP}$ & 39.4 & 18.4 & 63 & 126 \\
\hline \multirow[b]{2}{*}{ Ash tree } & $\mathrm{C}$ & 37.4 & 18.4 & 120 & 38 \\
\hline & $\mathrm{AP}$ & 42.3 & 21.7 & 129 & 51 \\
\hline \multirow{3}{*}{ Cypress } & $\mathrm{C}$ & 45.7 & 15.3 & 48 & 82 \\
\hline & AP & 64.3 & 10.8 & 44 & 114 \\
\hline & $\mathrm{TP}$ & 49.3 & 19.7 & 56 & 101 \\
\hline \multirow[b]{2}{*}{ Black pine } & $\mathrm{C}$ & 25.7 & 16.8 & 69 & 63 \\
\hline & $\mathrm{AP}$ & 29.5 & 19.4 & 75 & 65 \\
\hline \multirow{3}{*}{ Aspen } & $\mathrm{C}$ & 60.7 & 19.6 & 42 & 128 \\
\hline & $\mathrm{AP}$ & 63.7 & 15.2 & 48 & 146 \\
\hline & TP & 42.6 & 19.5 & 46 & 122 \\
\hline
\end{tabular}


Table 6. ANOVA results for $\mathrm{H}_{2} \mathrm{O}_{2}$ and MDA data.

\begin{tabular}{|c|c|c|c|c|c|c|}
\hline & Source & $\begin{array}{c}\text { Type III } \\
\text { Sum of } \\
\text { Squares }\end{array}$ & df & $\begin{array}{c}\text { Mean } \\
\text { Square }\end{array}$ & $\mathbf{F}$ & $\begin{array}{c}\text { Partial } \\
\text { Eta } \\
\text { Squared }\end{array}$ \\
\hline \multirow{8}{*}{$\mathrm{H}_{2} \mathrm{O}_{2}$} & Tree species (TS) & 30430,606 & 5 & 6086,121 & $68782,254 * * *$ & 1,000 \\
\hline & Pollution Type (PT) & 2557,457 & 2 & 1278,728 & $14451,539 * * *$ & 998 \\
\hline & Time $(\mathrm{T})$ & 7435,877 & 1 & 7435,877 & $84036,515 * * *$ & 999 \\
\hline & $\mathrm{TS} \times \mathrm{PT}$ & 2207,322 & 10 & 220,732 & $2494,603 * * *$ & 997 \\
\hline & $\mathrm{TS} \times \mathrm{T}$ & 74526,118 & 4 & 18631,529 & $210564,096 * * *$ & 1,000 \\
\hline & PT x T & 1640,138 & 2 & 820,069 & $9268,006^{* * *}$ & ,996 \\
\hline & $\mathrm{TS} \times \mathrm{PT} \times \mathrm{T}$ & 3646,363 & 8 & 455,795 & $5151,169 * * *$ & 998 \\
\hline & error & 5,840 & 66 & ,088 & & \\
\hline \multirow{8}{*}{ MDA } & Tree species (TS) & 2363,819 & 5 & 472,764 & $9361,798 * * *$ & ,999 \\
\hline & Pollution Type (PT) & 232,319 & 2 & 116,160 & $2300,223 * * *$ & 986 \\
\hline & Time $(\mathrm{T})$ & 17508,822 & 1 & 17508,822 & $346714,515 * * *$ & 1,000 \\
\hline & $\mathrm{TS} \times \mathrm{PT}$ & 856,739 & 10 & 85,674 & $1696,538 * * *$ & ,996 \\
\hline & $\mathrm{TS} \times \mathrm{T}$ & 3471,738 & 4 & 867,935 & $17187,079 * * *$ & 999 \\
\hline & PT x T & 996,637 & 2 & 498,318 & $9867,837 * * *$ & ,997 \\
\hline & $\mathrm{TS} \times \mathrm{PT} \times \mathrm{T}$ & 943,701 & 8 & 117,963 & $2335,928 * * *$ & ,996 \\
\hline & error & 3,333 & 66 &, 050 & & \\
\hline
\end{tabular}

\section{Variation in mean enzymatic antioxidant (APX, CAT and SOD)}

Mean concentrations of mean enzymatic antioxidant (APX, CAT and SOD) in the leaf and needle samples of six tree species collected in April and July and exposed to air and traffic pollutions are shown in Table 7.

The single effects and interactions of tree species, pollution types and sample colleting time are listed in Table 8. The main effects of species, pollution type and time on mean enzymatic antioxidant were all significant $(\mathrm{P}<0.001)$. Tree species $\mathrm{x}$ pollution types $\mathrm{x}$ time interactions were also significant for mean enzymatic antioxidant were indicating that mean enzymatic antioxidant were behave in different ways with the different pollution type and time according to tree species. Mean APX concentration in April samples for all 6 tree species were higher than in July samples, whereas mean CAT and SOD concentrations in April samples were much lower than in July samples. Although variation in mean enzymatic antioxidant concentration was depended on tree species and time, in general, compared to the control samples, mean enzymatic antioxidant concentrations in the air polluted samples were much higher than in the traffic polluted samples (Table 7).

Table 7. Mean enzymatic antioxidant concentrations in fresh leaves of 6 different tree species collected from air (AP) and traffic polluted (TP) and control (C) sites at two different times (April and July).

\begin{tabular}{cccccccc}
\hline \multirow{2}{*}{$\begin{array}{c}\text { Tree } \\
\text { species }\end{array}$} & \multirow{2}{*}{$\begin{array}{c}\text { Pollution } \\
\text { Type }\end{array}$} & \multicolumn{2}{c}{$\begin{array}{c}\text { APX } \\
\text { EU/mg Protein }\end{array}$} & \multicolumn{2}{c}{ CAT } & \multicolumn{2}{c}{$\begin{array}{c}\text { EOD } \\
\text { EUg Protein }\end{array}$} \\
\cline { 2 - 7 } Maple & April & July & April & July & April & July \\
\hline \multirow{3}{*}{ Ash tree } & C & 0.641 & 0.138 & 0.088 & 0.759 & 17 & 92 \\
& AP & 0.909 & 0.153 & 0.077 & 0.491 & 25 & 132 \\
& TP & 0.468 & 0.181 & 0.091 & 0.538 & 15 & 114 \\
\hline \multirow{3}{*}{ Cypress } & C & 0.640 & 0.148 & 0.057 & 0.880 & 17 & 93 \\
& AP & 0.785 & 0.167 & 0.053 & 0.601 & 24 & 101 \\
& TP & 0.530 & 0.103 & 0.055 & 0.546 & 16 & 102 \\
\hline \multirow{3}{*}{ Black pine } & C & 0.723 & 0.209 & 0.099 & 0.660 & 17 & 103 \\
& AP & 0.812 & 0.163 & 0.114 & 0.600 & 26 & 111 \\
& TP & 0.876 & 0.216 & 0.107 & 0.620 & 22 & 101 \\
\hline
\end{tabular}


Table 7 (continued)

\begin{tabular}{cccccccc}
\hline \multirow{3}{*}{ Sycamore } & $\mathrm{C}$ & n.a. & 0.266 & n.a. & 0.523 & n.a. & 71 \\
& $\mathrm{AP}$ & n.a. & 0.235 & n.a. & 0.473 & n.a. & 64 \\
& $\mathrm{TP}$ & n.a. & 0.248 & n.a. & 0.513 & n.a. & 87 \\
\hline \multirow{3}{*}{ Aspen } & $\mathrm{C}$ & 0.641 & 0.138 & 0.088 & 0.759 & 17 & 92 \\
& $\mathrm{AP}$ & 0.909 & 0.153 & 0.076 & 0.491 & 25 & 132 \\
& $\mathrm{TP}$ & 0.468 & 0.181 & 0.091 & 0.538 & 15 & 114 \\
\hline
\end{tabular}

Table 8. ANOVA results for APX, CAT, SOD.

\begin{tabular}{|c|c|c|c|c|c|c|}
\hline & Source & $\begin{array}{l}\text { Type III Sum } \\
\text { of Squares }\end{array}$ & df & $\begin{array}{l}\text { Mean } \\
\text { Square }\end{array}$ & $\mathbf{F}$ & $\begin{array}{c}\text { Partial Eta } \\
\text { Squared }\end{array}$ \\
\hline \multirow{8}{*}{ APX } & Tree species (TS) & ,187 & 5 & 037 & $1136,900^{* * *}$ & ,989 \\
\hline & Pollution Type (PT) & ,028 & 2 & 014 & $429,931 * * *$ & ,929 \\
\hline & Time (T) & 6,026 & 1 & 6,026 & $182701,406^{* * *}$ & 1,000 \\
\hline & TS x PT & 244 & 10 & ,024 & $738,525 * * *$ & 991 \\
\hline & TS $x \mathrm{~T}$ & 217 & 4 & 054 & $1646,836^{* * *}$ & ,990 \\
\hline & PT $x$ T & 050 & 2 & 025 & $753,527 * * *$ & 958 \\
\hline & $\mathrm{TS} \times \mathrm{PT} \times \mathrm{T}$ & 267 & 8 & 033 & $1011,390^{* * *}$ & ,992 \\
\hline & error &, 002 & 66 & $3,30 \mathrm{E}-005$ & & \\
\hline \multirow{8}{*}{ CAT } & Tree species (TS) & 215 & 5 &, 043 & $2640,719 * * *$ & ,995 \\
\hline & Pollution Type (PT) & 055 & 2 & 028 & $1702,675^{* * *}$ & ,981 \\
\hline & Time (T) & 5,782 & 1 & 5,782 & $355455,220 * * *$ & 1,000 \\
\hline & TS x PT & ,115 & 10 &, 012 & $707,019^{* * *}$ & ,991 \\
\hline & $\mathrm{TS} \times \mathrm{T}$ & 140 & 4 & 035 & $2152,254 * * *$ & 992 \\
\hline & PT $x$ T & ,045 & 2 & ,022 & $1373,898^{* * *}$ & 977 \\
\hline & TS $x$ PT $x T$ & ,135 & 8 & ,017 & $1037,290^{* * *}$ & 992 \\
\hline & error & 001 & 66 & $1,63 \mathrm{E}-005$ & & \\
\hline \multirow{8}{*}{ SOD } & Tree species (TS) & 6227,455 & 5 & 1245,491 & $3940,881 * * *$ & 997 \\
\hline & Pollution Type (PT) & 1125,214 & 2 & 562,607 & $1780,155^{* * *}$ & ,982 \\
\hline & Time (T) & 124058,630 & 1 & 124058,630 & $392536,244 * * *$ & 1,000 \\
\hline & TS x PT & 1988,808 & 10 & 198,881 & $629,282 * * *$ & 990 \\
\hline & $\mathrm{TS} \times \mathrm{T}$ & 6238,326 & 4 & 1559,581 & $4934,701 * * *$ & 997 \\
\hline & PT $x$ T & 327,004 & 2 & 163,502 & $517,340 * * *$ & ,940 \\
\hline & TS $x$ PT $x T$ & 1212,811 & 8 & 151,601 & $479,685^{* * *}$ & 983 \\
\hline & error & 20,859 & 66 &, 316 & & \\
\hline
\end{tabular}

Variation in non-enzymatic antioxidant (carotenoid, flavonoid, phenolic, proline and protein)

Mean concentrations of carotenoid, flavonoid, phenolic, proline and protein in the leaf and needle samples of six tree species collected in April and July and exposed to air and traffic pollutions are shown in Table 9. The single effects and interactions of tree species, pollution types and sample colleting time are listed in Table 10. The main effects of species, pollution type and time on carotenoid, flavonoid, phenolic, proline and protein were all significant $(\mathrm{P}<0.001)$. Tree species $\mathrm{X}$ pollution types $\mathrm{x}$ time interactions were also significant for carotenoid, flavonoid, phenolic, proline and protein indicating that carotenoid, flavonoid, phenolic, proline and protein behave in different ways with the different pollution type and time according to tree species. Although there were statistically significant variations in mean carotenoid, flavonoid and phenolic concentrations among the six tree species, the pollution types and time, they acted different ways with the pollution types and time according to tree species. For example, in April samples, mean carotenoid concentration in Maple control leaves $(9.63 \mathrm{mg} / \mathrm{g})$ was lower than those in the air polluted leaves $(10.5 \mathrm{mg} / \mathrm{g})$, but similar to those in the traffic polluted leaves (9.61 $\mathrm{mg} / \mathrm{g}$ ). In July, mean carotenoid concentration showed a decrease, but this time, mean carotenoid concentration in Maple control leaves $(4.59 \mathrm{mg} / \mathrm{g})$ was lower than both the air polluted leave $(6.13 \mathrm{mg} / \mathrm{g})$ and the traffic polluted leaves $(8.37 \mathrm{mg} / \mathrm{g})$. Similar results 
were noted for the other species and the flavonoid and phenolic concentrations (Table 9).

Mean proline and protein concentrations, however, showed more clear indications between the six tree species and time. In general, all tree species had much higher concentrations in July samples than in April samples (Table 9). However, variation in mean proline and protein concentrations among the pollution types did not show clear directions (Table 9).

Table 9. Mean non-enzymatic antioxidant concentrations in fresh leaves of 6 different tree species collected from air (AP) and traffic polluted (TP) and control (C) sites at two different times (April and July).

\begin{tabular}{|c|c|c|c|c|c|c|c|c|c|c|c|}
\hline \multirow{2}{*}{$\begin{array}{l}\text { Tree } \\
\text { species }\end{array}$} & \multirow{2}{*}{$\begin{array}{l}\text { Pollution } \\
\text { Type }\end{array}$} & \multicolumn{2}{|c|}{$\begin{array}{c}\text { Carotenoid } \\
\mathrm{mg} / \mathrm{g} \\
\end{array}$} & \multicolumn{2}{|c|}{$\begin{array}{c}\text { Flavonoid } \\
\mu \mathrm{g} / \mathrm{g}\end{array}$} & \multicolumn{2}{|c|}{$\begin{array}{c}\text { Phenolic } \\
\mu \mathrm{g} / \mathrm{g}\end{array}$} & \multicolumn{2}{|c|}{$\begin{array}{l}\text { Proline } \\
\mu \mathrm{mol} / \mathrm{g}\end{array}$} & \multicolumn{2}{|c|}{$\begin{array}{c}\text { Protein } \\
\text { mg/g }\end{array}$} \\
\hline & & April & July & April & July & April & July & April & July & April & July \\
\hline \multirow{3}{*}{ Maple } & $\mathrm{C}$ & 9.63 & 4.59 & 2.05 & 2.23 & 6.61 & 9.85 & 4.53 & 15.8 & 79.6 & 150 \\
\hline & AP & 10.5 & 6.13 & 2.34 & 3.86 & 7.00 & 10.5 & 3.18 & 17.6 & 86.5 & 171 \\
\hline & $\mathrm{TP}$ & 9.61 & 8.37 & 2.09 & 3.27 & 7.53 & 9.76 & 4.15 & 18.8 & 71.5 & 166 \\
\hline \multirow{3}{*}{ Ash tree } & $\mathrm{C}$ & 10.8 & 7.20 & 4.32 & 6.39 & 12.2 & 12.6 & 8.93 & 20.8 & 70.5 & 152 \\
\hline & AP & 11.0 & 9.68 & 4.01 & 10.5 & 12.4 & 8.19 & 10.8 & 18.4 & 93.1 & 159 \\
\hline & $\mathrm{TP}$ & 10.0 & 11.1 & 4.31 & 12.3 & 9.66 & 9.30 & 10.4 & 14.2 & 64.4 & 157 \\
\hline \multirow{3}{*}{ Cypress } & $\mathrm{C}$ & 9.61 & 9.60 & 3.43 & 4.30 & 8.47 & 10.9 & 3.97 & 43.4 & 67.4 & 161 \\
\hline & AP & 9.64 & 15.1 & 3.64 & 5.60 & 14.5 & 20.3 & 3.55 & 17.4 & 83.8 & 163 \\
\hline & TP & 9.61 & 10.2 & 2.87 & 4.27 & 15.1 & 19.1 & 4.20 & 18.6 & 79.8 & 157 \\
\hline \multirow{3}{*}{$\begin{array}{l}\text { Black } \\
\text { pine }\end{array}$} & $\mathrm{C}$ & 10.4 & 11.7 & 3.59 & 4.53 & 16.4 & 15.2 & 10.7 & 28.7 & 73.8 & 153 \\
\hline & AP & 11.5 & 9.11 & 3.98 & 4.48 & 15.3 & 13.0 & 12.1 & 31.5 & 95.8 & 150 \\
\hline & $\mathrm{TP}$ & 11.6 & 12.9 & 4.28 & 6.16 & 17.7 & 24.5 & 11.3 & 17.6 & 87.5 & 156 \\
\hline \multirow{3}{*}{ Sycamore } & $\mathrm{C}$ & n.a. & 12.2 & n.a. & 7.57 & n.a. & 18.5 & n.a. & 18.1 & n.a. & 155 \\
\hline & AP & n.a. & 13.6 & n.a. & 7.98 & n.a. & 27.8 & n.a. & 34.3 & n.a. & 157 \\
\hline & TP & n.a. & 10.1 & n.a. & 3.90 & n.a. & 13.8 & n.a. & 25.4 & n.a. & 151 \\
\hline \multirow{3}{*}{ Aspen } & $\mathrm{C}$ & 11.0 & 11.2 & 2.53 & 3.28 & 16.5 & 8.82 & 5.49 & 20.4 & 91.8 & 154 \\
\hline & AP & 9.49 & 11.0 & 3.55 & 2.86 & 16.6 & 6.51 & 4.11 & 17.9 & 81.7 & 165 \\
\hline & TP & 9.71 & 11.0 & 5.05 & 4.58 & 16.5 & 7.30 & 4.74 & 18.0 & 70.4 & 160 \\
\hline
\end{tabular}

Table 10. ANOVA results for non-enzymatic antioxidant data.

\begin{tabular}{ccccccc}
\hline Source & $\begin{array}{c}\text { Type III } \\
\text { Sum of } \\
\text { Squares }\end{array}$ & df & $\begin{array}{c}\text { Mean } \\
\text { Square }\end{array}$ & F & $\begin{array}{c}\text { Partial } \\
\text { Eta } \\
\text { Squared }\end{array}$ \\
\hline & Tree species (TS) & 130,479 & 5 & 26,096 & $1436,181^{* * *}$ &, 991 \\
& Pollution Type (PT) & 9,011 & 2 & 4,506 & $247,963 * * *$ &, 883 \\
Carotenoid & Time (T) & 2,873 & 1 & 2,873 & $158,112^{* * *}$ &, 706 \\
& TS x PT & 75,460 & 10 & 7,546 & $415,297 * * *$ &, 984 \\
& TS x T & 83,762 & 4 & 20,941 & $1152,463 * * *$ &, 986 \\
& PT x T & 15,319 & 2 & 7,659 & $421,540 * * *$ &, 927 \\
& TS x PT x T & 55,371 & 8 & 6,921 & $380,917 * * *$ &, 979 \\
& error & 1,199 & 66 &, 018 & &, 988 \\
& Tree species (TS) & 200,288 & 5 & 40,058 & $1068,542 * * *$ &, 786 \\
& Pollution Type (PT) & 9,101 & 2 & 4,550 & $121,382 * * *$ &, 966 \\
& Time (T) & 70,721 & 1 & 70,721 & $1886,497 * * *$ &, 967 \\
& TS x PT & 72,089 & 10 & 7,209 & $192,297 * * *$ &, 972 \\
& TS x T & 85,328 & 4 & 21,332 & $569,035 * * *$ &, 767 \\
& PT x T & 8,124 & 2 & 4,062 & $108,358 * * *$ &, 913 \\
& TS x PT x T & 26,107 & 8 & 3,263 & $87,051 * * *$ & \\
\hline error & 2,474 & 66 &, 037 & & & \\
\hline
\end{tabular}


Table 10 (continued)

\begin{tabular}{|c|c|c|c|c|c|c|}
\hline \multirow{8}{*}{ Phenolic } & Tree species (TS) & 1237,799 & 5 & 247,560 & $9904,731 * * *$ & ,999 \\
\hline & Pollution Type (PT) & 51,983 & 2 & 25,991 & $1039,905 * * *$ & ,969 \\
\hline & Time $(\mathrm{T})$ & 4,456 & 1 & 4,456 & $178,294 * * *$ & ,730 \\
\hline & $\mathrm{TS} \times \mathrm{PT}$ & 694,215 & 10 & 69,421 & $2777,515 * * *$ & ,998 \\
\hline & $\mathrm{TS} \times \mathrm{T}$ & 487,885 & 4 & 121,971 & $4880,003 * * *$ & ,997 \\
\hline & PT x T & 17,381 & 2 & 8,690 & $347,693 * * *$ & ,913 \\
\hline & $\mathrm{TS} \times \mathrm{PT} \times \mathrm{T}$ & 90,015 & 8 & 11,252 & $450,181 * * *$ & ,982 \\
\hline & error & 1,650 & 66 &, 025 & & \\
\hline \multirow{8}{*}{ Proline } & Tree species (TS) & 866,780 & 5 & 173,356 & $1831,161 * * *$ & ,993 \\
\hline & Pollution Type (PT) & 103,974 & 2 & 51,987 & $549,138 * * *$ & ,943 \\
\hline & Time $(\mathrm{T})$ & 4713,596 & 1 & 4713,596 & $49789,747 * * *$ & ,999 \\
\hline & $\mathrm{TS} \times \mathrm{PT}$ & 1227,396 & 10 & 122,740 & $1296,499 * * *$ & ,995 \\
\hline & $\mathrm{TS} \times \mathrm{T}$ & 501,197 & 4 & 125,299 & $1323,538 * * *$ & ,988 \\
\hline & $\mathrm{PT} \times \mathrm{T}$ & 280,415 & 2 & 140,208 & $1481,013 * * *$ & ,978 \\
\hline & $\mathrm{TS} \times \mathrm{PT} \times \mathrm{T}$ & 573,113 & 8 & 71,639 & $756,725 * * *$ & ,989 \\
\hline & error & 6,248 & 66 &, 095 & & \\
\hline \multirow{8}{*}{ Protein } & Tree species (TS) & 363,271 & 5 & 72,654 & $4,600 * * *$ & ,258 \\
\hline & Pollution Type (PT) & 1585,616 & 2 & 792,808 & $50,198 * * *$ & 603 \\
\hline & Time $(\mathrm{T})$ & 138202,475 & 1 & 138202,475 & $8750,503 * * *$ & ,993 \\
\hline & $\mathrm{TS} \times \mathrm{PT}$ & 851,045 & 10 & 85,105 & $5,389 * * *$ & ,449 \\
\hline & $\mathrm{TS} \times \mathrm{T}$ & 789,276 & 4 & 197,319 & $12,494 * * *$ &, 431 \\
\hline & PT x T & 451,793 & 2 & 225,896 & $14,303 * * *$ & ,302 \\
\hline & $\mathrm{TS} \times \mathrm{PT} \times \mathrm{T}$ & 1887,348 & 8 & 235,918 & $14,938 * * *$ & 644 \\
\hline & error &, 002 & 66 & $3,30 \mathrm{E}-005$ & & \\
\hline
\end{tabular}

\section{Discussion}

The impacts of air pollutants on vegetation have been studied since the early part of the 20th century, with effort being focused on sulfur dioxide, oxidized and reduced nitrogen, and ozone. Many authors have also stated that pollutant uptake depends on climatic conditions and the nature and extent of damage to plants depends on the chemistry and physical characteristics of the pollutant, and also on the plant's ability to detoxify it (Kozuharova, Nedyalkova, Gergov \& Simeonov, 2017; Szczepanska, Kudlak, Nedyalkova, Simeonov \& Namiesnik, 2017).

This present study investigated the variation in the photosynthetic pigments, oxidative stress, enzymatic and nonenzymatic compound using 6 different forest tree species exposed to the air pollution by the iron-steel factory and dense traffic. The results have shown that the chemical composition of tree leaves also significantly vary with air pollution, but the extent of the variations depends on the tree species, pollution types and season.
It has been known that photosynthetic pigments are the photoreceptors in photosynthesis that carry out the bulk of energy fixation by some pigments as chlorophyll-a, chlorophyll-b and carotenoid. Many researchers used chlorophyll as an index of productivity of plant by photosynthesis, and so understanding the amount, composition and variation of it between different plants and by the environmental factors received much attention (Cuming and Bennet 1981). The results in this present study have indicated that the photosynthetic pigments can significantly vary with plant species, pollution types and also seasons. We found that the pigment values in July were generally lower than those in April. However, both sampling periods we found significant differences in the pigment values between the six tree species and between the pollution types. The reactions of the trees to the pollution types in April, it was seen that total chlorophyll amount increased in the samples from Maple, Ash tree Cypress, Black pine and Aspen compared to the control samples. In addition, the ratios of 
chlorophyll $\mathrm{a} / \mathrm{b}$ were higher in Ash tree, Cypress and Aspen (Table 3, Table 4). In July, the amount of chlorophyll-a was noted higher in Maple, Ash tree, Black pine and Aspen, but total chlorophyll increased in Maple, Ash tree and Cypress compared to the control samples. The ratios of chlorophyll a/b in July were higher than those in April. This time, the ratios of chlorophyll $\mathrm{a} / \mathrm{b}$ were higher in Cypress, Sycamore and Aspen tree species (Table 3, Table 4).

In general, all results in this present study indicate that some certain pollutants increase the photosynthetic pigments as chlorophyll a, $\mathrm{b}$ and total chlorophyll contents, but the others decrease them. And also deposition and harmful effects of pollutant on pigment content varied according to the seasons. The results of this present study which studied the effects of pollutants by the vehicular exhausts and factory pollutions on the pigment content show similarities with the results obtained by other studies. Sharma et al. (2017) showed that total chlorophyll content varied significantly in different species, and the maximum chlorophyll was detected in Quercus sp. during the monsoon season. Gheorghe and Ion (2011) found that the older needles of conifers were more sensitive to $\mathrm{NO}_{2}$, and they were more damaged in spring and summer due to destruction of thylakoid membrane. Bhattacharya, Kriplani \& Chakraborty (2013) showed for six tree species that the amount of chlorophyll increased during monsoon while it decreased in winter and summer with the pollution. They also noted that the tolerant species had more pigment than the susceptible ones. In this present study, based on total chlorophyll, it was noted that Maple was more resistant to the traffic pollution, while Ash tree was more tolerant to both the pollution types. Among the all six trees species, Aspen was found more susceptible to the traffic pollution.

A number of authors stated that tolerant species maintained higher chlorophyll under polluted conditions. They also reported that deposition and harmful effects of pollutant on leaf samples varied according to the variations in seasonal parameters such as temperature level, wind direction, rainfall as well as sources of pollution, distance to them. A study by Wang, Shi \& Wang (2014) showed the highest pollutant accumulated on leaf surface was in August and the lowest in November. The small sized matters were tightly adhered to leaf surface, but larger substances were washed away by rain. Anoob, Santhoshkumar \& Roby (2017) showed that chlorophyll pigment amount decreased as pollution was heavier and dirt layer was highest in dry summer by the reason of long exposure time and not enough rainfall to wash the dust off the leaves. Prajapati and Tripathi (2008) showed that level of chlorophyll reduced with the increase of dust deposition and the maximum dust deposition was observed in winter by summer. On the other hand, Geeta and Namrata (2014) showed that chlorophyll-a and chlorophyll-b reduced in Industrial area in Alstonia and in Polyalthia, whereas the industrial area in Thevetia chlorophyll content increased.

As seen above, many studies have stated that air pollutants such as $\mathrm{SO}_{2}$ and $\mathrm{NO}_{2}$ (Hamid and Jawaid, 2009; Joshi and Swami, 2009) and the pollutants from the automobile exhaust such as the dust particles, metals and polycyclic hydrocarbons (Chauhan, 2010, Wittenberghe et al., 2013) deplete the photosynthetic pigments in plant leaves. Some authors have argued that the reduction of chlorophyll content in plant species due to pollution can be attributed to the breaking of chlorophyll molecules, blocking of biosynthesis of pigment pathway or functional enzymes activities in pathways or stimulating oxidative stress (Cakmak, 1994; Dubey and Pandey 2011). Other authors have stated that the destruction of chloroplast membrane by oxidant, the closing of stomata, the changing of the leaf sap $\mathrm{pH}$, photosynthetic electron transfers and redox reactions are the other effects of the pollution (Cunyan and Xuefeng, 2014; Geeta \& Namrata 2014). All these adverse effects by the pollution prevent leaf development, stimulate premature senescence and even cause death (Katiyar and Dubey 2001; Gheorghe \& Ion 2011). Chatterjee, Dube, Sinha \& Srivastava (2004) found that excess of heavy metals accumulation in leaf cell such as lead, iron, cadmium, and toxic compounds like $\mathrm{SO}_{2}$, $\mathrm{NO}_{2}$, volatiles and suspended substances 
prevented the incorporation of $\mathrm{Fe}$ in phytoporphyrin ring of chlorophyll molecule. Langmeier, Ginsburg \& Matile (1993) observed that high amount of $\mathrm{SO}_{2}$ destroyed chlorophyll structure by restraining $\mathrm{Mg}^{2+}$ insertion into protoporphyrin or $\mathrm{Mg}^{2+}$ in the chlorophyll molecule was replaced by two atoms of hydrogen thereby changing the light-spectrum characteristic of the chlorophyll molecules. The number authors have also noted that the pollutants can stimulate mineral insufficiency/toxicity in soil (Cakmak and Horst, 1991).

The environmental contaminants may stimulate oxidative stress and elevate the level of oxygen species (ROS) which cause oxidation of proteins, enzymes, DNA and others cellular components (Palma et al. 2002, Dubey \& Pandey, 2011). And also ROS increase MDA concentration due to disruption membrane structures by lipid peroxidation reactions (Fermer and Muller, 2013). But tolerant genotypes have inhibitors of lipid peroxidation reactions and detoxification mechanisms of ROS and efficiently as several non-enzymatic as well as enzymatic antioxidants. The nonenzymatic compounds consist of carotenoid, flavonoids, phenolics, proline and total soluble proteins (Takahama and Oniki, 2000, Sanaeirad, Majd, Hossein Abbaspour \& Peyvandi, 2017), while enzymatic antioxidants catalase (CAT), ascorbate peroxidase (APX), glutathione peroxidase (GPX), superoxide dismutase are formed which enhance the resistance of plants to pollution (Foyer and Noctor, 2011). We found that the MDA amount in July were generally lower than those in April but $\mathrm{H}_{2} \mathrm{O}_{2}$ concentration was higher in July in Maple, Cypress and Aspen. The APX activity decreased in July while the CAT and SOD activities increased significantly in July for all six tree species. The carotenoid amount did not show any significant changes, but Maple had the lowest concentrations compared to the other tree species in July. The amount of flavonoid in the leaf samples was higher in April compared to those in July, but it was low in Aspen leaves, except control leaves of Aspen in July. Total phenolic compound was higher for Maple and Cypress in July than in April, whereas for Aspen leaves, it decreased significantly compared to April. The amounts of proline and total soluble protein for the six tree species were significantly higher in July than in April. Much higher increase in proline and protein concentration was seen for Maple and Cypress in July. According to the literature, the higher activity of CAT and SOD was effective in decreasing the MDA level. A part from that, higher proline and soluble protein contents may have caused a reduction in the MDA content in July. And also being at the higher $\mathrm{H}_{2} \mathrm{O}_{2}$ concentration in April, but the lower CAT activity shows an inverse relation between the $\mathrm{H}_{2} \mathrm{O}_{2}$ and CAT activity. Those results are in line with the findings of Sanaeirad et al. (2017) who showed that the levels of proline and total protein was higher via to the nitrate reductase activity in Laurus nobilis growing in a polluted area, and also stated that broadleaf and evergreen plant can be used for monitoring pollution. Yan et al. (2010) for Quercus spp., Tiwari, Agrawal \& Marshall (2006) for carrot plants and Verma and Dubey (2003) for rice seedling reported that pollutants resulted in elevating the MDA level, the destructions of pigments molecules, and reductions of cell lipid. On the other hand, many studies indicated that there was an adverse interaction between the pollution and the oxidative stress, activity of enzymes and soluble osmolytes such as proline, soluble protein and reduced sugars. They can act as inhibitors of ROS overproduction and reducing agents' injuries in tolerant genotypes under pollution, drought and heavy metals and also they play important role in maintain of osmotic potential (Sharma, Villamor \& Verslues, 2011). Some authors showed that proline and soluble proteins increased in plant which contacted with the air pollutants (Mattioli, Costantino \& Trovato, 2009; Sanaeirad et al. 2017) and heavy metals (Wang et al., 2014), whereas the other showed that the pollutants decreased MDA level (Sofoa, Dichioa, Xiloyannisa \& Masiab, 2004). Woo, Lee \& Lee (2007) noted that as long as exposure to the pollution was prolonged, the MDA and ROS production was increased, but the accumulations of proline and protein led to increasing the resistance to the pollutants. Patykowski and Kołodziejek

(2016) 
investigated the seasonal pattern of activity of antioxidant enzymes as well as the soluble protein by pollution from at the beginning of May to at the end of November. The effects of pollutant on chemicals varied according to duration of pollution of mistletoe leaves, and the SOD activity was higher in autumn but the CAT activity increased in late spring. Seyyednejad, Koochak \& Vaezi (2013) also observed that industrial pollution increased the POD and CAT activity as well as ascorbic acid.

As non-enzymatic antioxidants, total phenolic and carotenoids have various functions in the protection of cellular components in plant species such as preventing of harmful effect of UV, photo inhibition of leaf by high light intensity, pollution, and heavy metal by chelating metals/contaminants (Michalak, 2006). Many authors reported that level of total phenolic, flavonols and also carotenoid increased with leaf maturation especial at the end of summer or autumn (Chandawat, Verma, Solanki, \& Patel 2014).

Takahama \& Oniki (2000), Prajapati \& Tripathi (2008) showed that the amount of total phenolic and carotenoids changed under stress factories in respect to seasons. Increasing of total phenolic and falvonols due to heavy metals, $\mathrm{SO}_{2}, \mathrm{NO}_{2}, \mathrm{RSPM}$, SPM and $\mathrm{O}_{3}$ was also shown by Michalak (2006) and Cordoba, Marquez-Garcia \& FernandezRecamales (2012). Pasqualini, Cannac, Greff Fernandez \& Ferrat (2007) found for pine tree that total phenolic increased after a prescribed burning from May to July. They stated that total phenolic compounds could be used as bio-indicators the impact of prescribed burning due to higher concentration in mature leaf. Muszyńska, Kałużny \& Hanus-Fajerska (2014) examined heavy metal effect on total phenolic, flavonols and anthocyanins in sea buckthorn which was collected in spring and autumn. They noted that total phenolic, especially levels of phenylpropanoids and flavonols were higher in the samples growing on the waste heaps. However, the amount total phenolic and flavonols vary with the leaf age and the season.

\section{Conclusion}

Many urban areas have high concentrations of air pollution sources resulting from human activities; sources such as iron-steel factory, motor vehicle traffic, power generation, residential heating and industry. It is known that tree planting has the ability to remove air pollutants from the atmosphere. On the other hand, the pollutants can enter inside of cellular structures, and also they change morphological, physiological and cellular properties of tree leaves. The results presented in this study have shown that leaf chemical compounds such as photosynthetic pigments, oxidative stress, and antioxidants system as enzymatic and non-enzymatic molecules vary significantly with the air pollution, but the extent of the variations are dependent on the tree species, pollution types and season. In general, the pigment values, MDA, $\mathrm{H}_{2} \mathrm{O}_{2}$ and APX, concentrations in July were lower than those in April, whereas CAT, SOD, proline and protein concentrations in July were higher than those in April. All the results were considered, it was noted that Maple was more resistant to the traffic pollution, while Ash tree was more tolerant to both the pollution types. Among the all six trees species, Aspen was found more susceptible to the traffic pollution. The results provided in this study could be used in the future research directions to improve our understanding of the role of individual tree species in air pollution reduction and also set up a healthy, well managed urban forest which can provide many ecological benefits to urban environment.

\section{Acknowledgements}

This paper, which was carried out and prepared outside the scope of the project, was conducted by utilizing the projects of KÜBAP-01/2013-17 and KÜBAP-01/201421.

\section{References}

Anoob, P., Santhoshkumar, A.V., \& Roby, P.C. (2017). Impact of particulate pollution on photosynthesis, transpiration and plant water potential of teak (Tectona grandis L.). Current Science, 112(6), 1272-1276. 
Arnon, D. I. (1949). Copper enzymes in isolated chloroplasts. Polyphenol oxidase in Beta vulgaris. Plant Physiology, 24, 1-15.

Bates, L. S., Waldern R. P. \& Teare I. D. (1973). Rapid determination of free proline for waterstress studies. Plant Soil, 39, 205-207.

Bayhan, Y. K. (2016). Effects of Some Plants Structure and the Metabolites of Cement Dust Emissions. Kastamonu University Journal of Forestry Faculty, 16(1), 147-152.

Bergmeyer, H. U. (1970). Methoden der Enzymatischen Analyse. Akademie Verlag, 1, 636-562.

Bhattacharya, T., Kriplani, L., \& Chakraborty, S. (2013). Seasonal Variation in Air Pollution Tolerance Index of Various Plant Species of Baroda City. Universal Journal of Environmental Research \& Technology, 3(2), 199-208.

Bradford, M. (1976). A Rapid and Sensitive Method for the Quantitation of Microgram Quantities of Protein Utilizing the Principle of Protein-Dye Binding. Annual Review of Biochemistry, 72, 248-254.

Cakmak, I. (1994). Activity of ascorbatedependent $\mathrm{H}_{2} \mathrm{O}_{2}$-scavenging enzymes and leaf chlorosis are enhanced in magnesium and potassium deficient leaves, but not in phosphorus deficient leaves. Journal of Experimental Botany, 45, 1259-1266.

Cakmak, I. \& Horst, W.J. (1991). Effect of Aluminium on lipid peroxidation, Superoxide dismutase, Catalase and Peroxidase activities in root tips of Soybean (Glycine max). Physiologia Plantarum, 83, 463-468.

Chandawat, D.K., Verma, P.U., Solanki H.A., Patel Y.M. (2014). Role of Total Phenol in The Resistance Mechanism of Plants Against Air Pollution. Biolife, 2(2),586-592.

Chatterjee, C., Dube, B.K., Sinha, P., \& Srivastava, P. (2004). Detrimental effects of lead phytotoxicity on growth, yield and metabolism of rice. Communications in Soil Science and Plant Analysis, 35(1,2), 255-265.

Chauhan, A. (2010). Photosynthetic Pigment Changes in Some Selected Trees induced by Automobile Exhaust in Dehradun, Uttarakhand. New York Science Journal, 3(2), 45-51.

Cordoba, F., Marquez-Garcia, B., \& FernandezRecamales, A. (2012). Effects of Cadmium on Phenolic Composition and Antioxidant Activities of Erica andevalensis. Journal of Botany, 12, 1- 6.

Cuming, A.C. \& Bennet, J. (1981). Biosynthesis of the Light-Harvesting Chlorophyll $a / b$ Protein Control of Messenger RNA Activity by Light. European Journal of Biochemistry., $118,71-80$.

Cunyan, W. \& Xuefeng, W. (2014). Effects of foliar dust on plant reflectance spectra and physiological ecology. Chinese Journal of Applied \& Environmental Biology, 6,11321138.

Çavuşoğlu, K., Kılıç, S. \& Kılıç, M. (2009). Effects of lead $(\mathrm{Pb})$ pollution caused by vehicles on the anatomy of pine (Pinus nigra Arn. subsp. pallasiana) and cedar (Cedrus libani A. Rich.) leaves. Biological Conservation, 2(3), 92-98.

Deniz, M. (2010). Effect of thermal power plant pollution on mineral nutrition and antioxidative defence mechanism on eucalyptus and morus species. Çukurova Unitversity Institute of Natural and Applied Sciences Department of Biology, Adana, Turkey.

Dubey, D. \& Pandey, A. (2011). Effect of nickel (Ni) on chlorophyll, lipid peroxidation and antioxidant enzymes activities in black gram (Vigna mungo) leaves. International Journal of Natural Sciences, 2(2), 395-401.

Fermer, E.F. \& Muller, M.J. (2013). Reactive oxygen species mediated lipid peroxidation and RES activated signaling. Annual Review of Plant Biology, 4,429-450.

Foyer, C.H. \& Noctor, G. (2011). Ascorbate and glutathione: the heart of the redox hub. Plant Physiology, 155, 2-18.

Geeta, C. \& Namrata, C. (2014). Effect of air pollution on the photosynthetic pigments of selected plant species along roadsides in Jamshedpur, Jharkhand. Research in Plant Biology, 4(5), 65-68.

Gheorghe, I.F. \& Ion, B. (2011). The effects of air pollutants on vegetation and the role of vegetation in reducing atmospheric pollution. The Impact of Air Pollution on Health, Economy, Environment and Agricultural Sources. Edit by Khalla, M.K. Chapter 12, DOI: $10.5772 / 17660$.

Halbwacts, G. (1984). Organismal responses of higher plants to atmospheric pollutants: sulphur dioxide and fluoride. Air pollution and Plant Life. Edit by Treshovv, M. Chapter 9, 175-213. John Wiley and Sons Ltd.

Hamid, N. \& Jawaid, F. (2009). Effect of short term exposure of two different concentrations of sulphur dioxide and nitrogen dioxide mixture on some biochemical parameter of soybean (Glycine max L. Merr.). Pakistan Journal of Botany, 41, 2223-2228.

Iqbal, M.Z. \& Shafig, M., Zaidi, Q.S., Athar, M. (2015). Effect of automobile pollution on 
chlorophyll content of roadside urban trees. Global Journal of Environmental Science and Management, 1(4),283-296.

Joshi, P.C. \& Swami, A. (2009). Air pollution induced changes in the photosynthetic pigments of selected plant species. Journal of Environmental Biology, 30, 295-298.

Katiyar, V. \& Dubey, P.S. (2001). Sulphur dioxide sensitivity on two stage of leaf development in a few tropical tree species, Indian Journal of Environment and Toxicology, 11,78-81.

Keller, J. \& Lamprecht, R. (1995). Road dust as an indicator for air pollution transport and deposition: An application of SPOT imagery. Remote Sensing of Environment, 54,1-12.

Kozuharova, E., Nedyalkova, M., Gergov, G. \& Simeonov, V. (2017). Multivariate statistical classification of plant features - the case with onobrychis pindicola subsp. Urumovii degen \& dren. Comptes rendus de l'Academie bulgare des Sciences, 70(11), 1531 - 1538.

Kumaran, A. \& Karunakaran, R.J. (2006). Antioxidant and free radical scavenging activity of an aqueous extract of Coleus aromaticus. Food Chemistry, 97, 109-114.

Langmeier, M. \& Ginsburg, S., Matile, P. (1993). Chlorophyll breakdown in senescent leaves: demonstration of $\mathrm{Mg}$-dechelatase activity. Physiologia Plantarum, 89, 347-353.

Lutts, S., Kinet, J.M. \& Bouharmont, J. (1996). $\mathrm{NaCl}$-Induced senescence in leaves of rice (Oryza sativa L.) Cultivars differing in salinity resistance. Annals of Botany, 78, 389398.

Mattioli, R., Costantino, P. \& Trovato, M. (2009). Proline accumulation in plants- not only stress. Plant Signaling \& Behavior, 4, 10161018.

Michalak, A. (2006). Phenolic compounds and their antioxidant activity in plants growing under heavy metal stress. Polish Journal of Environmental Studies, 15(4), 523-530.

Miller, P.R. \& McBride, J. (1999). Oxidant air pollution impacts in the montane forests of southern california: The San Bernadino Mountain Case Study. New York: SpringerVerlag.

Muszyńska, E., Kałużny, K. \& Hanus-Fajerska, E. (2014). Phenolic compounds in Hippophä̈ rhamnoides leaves collected from heavy metals plants in urban areas and landscape. Slovak University of Agriculture in Nitra, Faculty of Horticulture and Landscape Engineering, 11-14.

Mutlu, S., Atıcı, Ö. \& Kaya, Y. (2009). Effect of cement dust on the diversity and the antioxidant enzyme activities of plants growing around a cement factory. Fresenius Environmental Bulletin, 18(10),1823-1827.

Nakano, Y. \& Asada, K. (1981). Hydrogen peroxide is scavenged by ascorbate-spesific peroxidase in spinach chloroplasts. Plant and Cell Physiology, 22(5), 867-880.

Oleksyn, J. (1988). Height growth of different European Scot pine (Pinus sylvestris L.) provenances in a heavily polluted and a control environment. Environmental Pollution, 55(4), 289-299.

Palma, J.M., Sandalino, L.M., Corpas, F.J., Romero- Puertas, M.C., McCharty, I. \& Del Rio, L.A. (2002). Plant proteases, protein degradation, and oxidative stress: Role of peroxisomes. Plant Physiology and Biochemistry, 40,521-530.

Pandey, J. \& Agrawal, M. (1994). Evaluation of air pollution phytotoxicity in a seasonally dry tropical urban environment using three woody perennials. New Phytologist, 126(1), 53-61.

Pasqualini, V., Cannac, M., Greff, S., Fernandez, C. \& Ferrat, L. (2007). Characterization of phenolic compounds in Pinus laricio needles and their responses to prescribed burnings. Molecules, 12, 1614-1622.

Patykowski, J. \& Kołodziejek, J. (2016). Changes in antioxidant enzyme activities of european mistletoe (Viscum album L. subsp. album) Leaves as a response to environmental stress caused by pollution of the atmosphere by nitrogen dioxide. Polish Journal of Environmental Studies, 25(2):725-732.

Prajapati, S.K. \& Tripathi, B.D. (2008). Seasonal variation of leaf dust accumulation and pigment content in plant species exposed to urban particulates pollution. Journal of Environmental Quality, 37, 865-870.

Prusty, B.A.K., Mishra, P.C. \& Azeez, P.A. (2005). Dust accumulation and leaf pigment content in vegetation near the national highway at Sambalpur, Orissa, India. Ecotoxicology and Environmental Safety, 60(2), 228-235.

Pukacka, S. \& Pukacki, P.M. (2000). Seasonal changes in antioxidant level of Scots pine (Pinus sylvestris L.) needles exposed to industrial pollution. I. ascorbate and thiol content. Acta Physiologiae Plantarum. 22, 451-456.

Sanaeirad, H., Majd, A., Hossein Abbaspour, H. \& Peyvandi, M. (2017). The effect of air pollution on proline and protein content and activity of nitrate reductase enzyme in Laurus nobilis L. Plants. Journal of Molecular Biology, 7(1),99-104. 
Sarıyıldız, T., Savacı, G. \& Aljazwei H.A.A. (2017). Assessing the potential for zinc, copper, lead and cadmium phytoremediation with oat plants (Avena sativa Linn.). Ecology Symposium. Kayseri, Turkey.

Seinfeld, H. (1986). Atmospheric chemistry, and physics of air pollution. Wiley. New York.

Seyyednejad, S., Koochak, H. \& Vaezi, J. (2013). Changes in antioxidative enzymes activity, protein content and ascorbic acid level in Prosopis juliflora exposed to industrial air pollution. Journal of Biology and Today's World, 10,482-492.

Sharma, A. \& Tripathi, D.B. (2009). Biochemical responses in tree foliage exposed to coal fired power plant emission in seasonally dry tropical environment. Environmental Monitoring and Assessment, 158(4), 197-212.

Sharma, B., Sharma, S. \& Bhardwaj, S.K., Alam, N.M., Parmar, Y.S. (2017). Effect of pollution on total chlorophyll content in temperate species growing along national highway 5 in himachal pradesh. Proceedings of ASAR international conference. New Delhi, India.

Sharma, S., Villamor, J.G. \& Verslues, P.E. (2011). Essential role of tissue-specific proline synthesis and catabolism in growth and redox balance at low water potential. Plant Physiology, 157, 292-304.

Singleton, V.L., Orthofer, R. \& LamuelaRaventós, R.M. (1999). Analysis of total phenols and other oxidation substrates and antioxidants by means of Folin-Ciocalteu reagent. Methods in Enzymology, 299, 152178.

Sofoa, A., Dichioa B., Xiloyannisa, C. \& Masiab, A. (2004). Lipoxygenase activity and proline accumulation in leaves and roots of olive trees in response to drought stress. Plant Physiology, 121, 58-65.

Szczepanska, N., Kudlak, B., Nedyalkova, M., Simeonov, V. \& Namiesnik J. (2017). Application of chemometric techniques in studying of toxicity of selected commercially available products for infants and children. Environmental Monitoring and Assessment. 189, 309.

Takahama, U. \& Oniki, T. (2000). Flavonoid and some other phenolics as substrates of peroxidase: physiological significance of the redox reactions. Journal of Plant Research, 113,301 .

Tiwari S., Agrawal, M. \& Marshall, F.M. (2006). Evaluation of ambient air pollution impact on carrot plants at a suburban site using open top chambers. Environmental Monitoring and Assessment, 119,15-30.
Tobiszewski, M, Nedyalkova, M., Madurga, S., Pena-Pereirad, F., Namieśnika, J. \& Simeonov, V. (2018). Pre-selection and assessment of green organic solvents by clustering chemometric tools. Ecotoxicology and Environmental Safety. 147: 292-298.

Tripathi, A.K. \& Gautam, M. (2007). Biochemical parameters of plants as indicators of air pollution. Journal of Environmental Biology, 28(1), 127-132.

Velikova, V., Yordanov, I. \& Edreva, A. (2000). Oxidative stress and some antioxidant systems in acid rain-treated bean plants: protective roles of exogenous polyamines. Plant Science, 151, 59-66.

Verma, S. \& Dubey, R.S. (2003). Leads toxicity induces lipid peroxidation and alters the activities of antioxidant enzymes in growing rice plants. Plant Science, 164, 645-655.

Wang, H., Shi, H. \& Wang, Y. (2014). Effects of Weather, Time, and Pollution Level on the Amount of Particulate Matter Deposited on Leaves of Ligustrum lucidum. The Scientific World Journal, 2015, 1-8.

Witham, F.H. \& Blaydes, D.F., Devli, R.M. (1971). Experiments in plant physiology. (5556). Van Nostrand Reinhold Company, New York.

Wittenberghe, S.V., Alonso, L., Verrelst, J., Hermans, I., Delegido, J., Veroustraete, F., Valcke, R., Moreno, J. \& Samson, R. (2013). Upward and downward solar-induced chlorophyll fluorescence yield indices of four tree species as indicators of traffic pollution in Valencia. Environmental Pollution, 173, 2937.

Woo, S.Y., Lee, D.K. \& Lee, Y.K. (2007). Net photosynthetic rate, ascorbate peroxidase and glutathione reductase activities of Erythrina orientalis in polluted and non-polluted areas. Photosynthetica, 45(2), 293-295.

Yan, K., Chen, W., He, X., Zhang, G., Xu, S. \& Wang, L. (2010). Responses of photosynthesis, lipid peroxidation and antioxidant system in leaves of Quercus mongolica to elevated $\mathrm{O}_{3}$. Environmental and Experimental Botany, 69,198-204.

Yang, J., McBride, J., Zhou, J. \& Sun, Z. (2005). The urban forest in Beijing and its role in air pollution reduction. Urban Forestry \& Urban Greening. 3, 65-78.

Yilmaz, T. (2015). The effect of heavy metals (lead, zinc, copper and cadmium) on the chlorophyll content of some mosses. MSc Thesis (59 pages), Graduate School of Natural and Applied Sciences Department. 